\title{
INVESTOR SENTIMENT AND MISPRICING ANOMALIES
}

\author{
Jiarui Dai \\ High School Affiliated to Shanghai Jiao Tong University \\ daijiarui2013@icloud.com
}

\begin{abstract}
This paper attempts to investigate the effect of investor sentiment on mispricing anomalies, including value premium, earnings to price, gross profitability, operating profitability, return to assets, and V/P ratio. Via bi-variate analysis and regression analysis, I find these anomalies are stronger in the periods with higher investor sentiment. The effect is robust after controlling for Fama-French three factors. The results are consistent with the idea that investors are more likely to misprice stocks when investor sentiment is high, leading stronger mispricing anomalies in such higher investor sentiment periods. The limitation of this study is that it only includes tests for six misplacing anomalies and does not cover the detection of a large number of anomalies.

The value of this study is it is the first study to investigate the effect of investor sentiment on $\mathrm{V} / \mathrm{P}$ anomaly and to explore these misplacing anomalies as a whole. More importantly, through this study, I actually tested the impact of investor sentiment on investor valuation accuracy.
\end{abstract}

Keywords: Investor Sentiment, Mispricing, Anomaly

Copyright @ 2020, International Journal of Economics, Business and Entrepreneurship | IJEBE | FEB-UNILA

\section{INTRODUCTION}

Whether investor sentiment affects mispricing anomalies is a focal topic for financial economists in the last decade. A rich stream of recent papers show that investor sentiment plays an important role in determining stock prices. For instance, Baker and Wurgler (2006) not only find that investor sentiment affects the cross-section of stock returns but also confirm that investor sentiment has larger effects on securities whose valuations are highly subjective and difficult to arbitrage. Along this line of research, Stambaugh, Yu and Yuan (2012) further explore the role of investor sentiment in cross-sectional stock returns anomalies and find that most anomalies provide profits from their short leg and are stronger when investor sentiment is high.

To push forward this line of literature and investigate the effect of investor sentiment on investors' valuation accuracy, this study explores the impact of investor sentiment on mispricing anomalies, including value premium, earnings to price, gross profitability, operating profitability, return to assets, and V/P ratio. Among all anomalies, these anomalies are caused at least partially due to the mispricing from investors and generate profits from value recovery. Therefore, this offers 
us an opportunity to test the relationship between investor sentiment and investors' valuation accuracy.

I begin the investigation with a validation on the aforementioned mispricing anomalies. I focus my analyses on value premium (Fama and French, 1992), earnings to price (Ball, 1978), gross profitability (Novy-Marx, 2013), operating profitability (Ball et al., 2015), return to assets (Chen, Novy-Marx and Zhang, 2011), and V/P ratio (Frankel and Lee, 1998) because these measures are shown to have stock return predictability, are caused at list partially due to mispricing from investors, and are incrementally different from each other by just a few accounting variables. Following Stambaugh, Yu and Yuan (2012), I first construct the long portfolio, short portfolio and long-short portfolio for value premium, earnings to price, gross profitability, operating profitability, return to assets, and $\mathrm{V} / \mathrm{P}$ ratio based on sorted decile portfolios. The results show that these anomalies are still robust in the period from 1970 to 2018.

Then, to explore the impact of investor sentiment on the mispricing anomalies, I adopt two methods. First, I conduct a bivariate analysis. Based on the sorted decile portfolios in the univariate analysis, I split the sample period into high sentiment period and low sentiment period according to the median investment sentiment of the whole sample period, and compare the next-month return of anomalies between the high sentiment periods and the low sentiment periods. The result of this analysis suggests that for all these anomalies in long-short portfolios, investors with high sentiment get higher returns than those with the low sentiment. By contrast, in long and short portfolios, investors with low sentiment undervalue stocks as the actual portfolio returns are higher.

Then, I conduct a regression analysis by regressing the return of anomalies over last-month investor sentiment. The new results for long-short portfolios roughly remain unchanged, which shows these mispricing anomalies have substantial effects on return when sentiment is high. However, earnings-to-price and GP becomes more significant in the long portfolio, but earnings-toprice is no longer significant in the short portfolio. Thus for earnings-to-price is weaker in the short portfolio, and stronger in the long portfolio.

Through bi-variate analysis and regression analysis, I find these anomalies are stronger in the periods with higher investor sentiment. To control the reverse causality, I use the investor sentiment from the last month. After controlling for the Fama-French three factors, the effects remain robust. The results are consistent with the idea that investors are more likely to misprice stocks when investor sentiment is high, leading stronger mispricing anomalies in such higher investor sentiment periods.

The rest of paper is organized as follows. Section 2 will be the literature review. Section 3 discusses the data source, and anomaly construction. Section 4 uses univariate and bi-variate analysis and regression analysis to describe returns on the long-short portfolio, long portfolio and short portfolio constructed for each of the six anomalies. Section 5 summarizes the whole paper.

\section{LITERATURE REVIEW}

Value premium: Fama and French(1992) showed that there is a strong corss-sectional relationship between the book-to-market equity and average stock return. Following Fama and French (1992, 1993, and 2000), book-to-market ratio is computed as the book value of stockholders' equity, plus deferred taxes and investment tax credit (if available), minus the book value of preferred stock for the last fiscal year end in $t-1$, scaled by the market value of equity at 
end of December of $t-1$ and finally taking natural logarithm.

Earnings to price: Ball(1978) showed earning to price is a comprehensive proxy for omitted risk factors in expected returns; earnings-to-price for stocks with higher risk and expected return may be higher, regardless of the unnamed source of risk. While Fama and French(1992) argued this finding makes sense only when the firm receives positive earnings. When the current earning is negative, earnings-to-price cannot be the proxy for the expected return. Following Ball (1978) earnings-to-price ratio is calculated as the earnings-to-price available on portfolio formation date scaled by the last price available for that date.

Gross profitability: Novy-Marx (2013) explored that profitability has approximately same predictive power on the cross-section of average return as book-to-market. The average return for profitable firm is higher than unprofitable firms. He also believed that gross profit is the cleanest accounting measure of the true economic profitability.

Operating profitability: Ball et al. (2015) raise that operating profitability better matches current expenses with current revenue than net income and gross profitability. They find that operating profitability exhibits a far stronger link with expected returns than either net income or gross profit. It predicts returns as far as ten years ahead, seemingly inconsistent with irrational pricing explanations. Following their study, I measure operating profitability as gross profits (net revenue minus cost of goods sold) scaled by total assets.

Return to assets: Chen, Novy-Marx and Zhang (2011) discover that firms with a higher return on assets earn in the past will have a significantly high subsequent return. Following their study, ROA in this paper is calculated as net income scaled by total assets.

V/P ratio: Frankel and Lee (1998) examine the usefulness of an analyst-based valuation model in predicting cross-sectional stock returns and estimate firms' fundamental values (V) using I/B/E/S consensus forecasts and a residual income model. They find that $\mathrm{V}$ is highly correlated with contemporaneous stock price, and that the V/P ratio is a good predictor of long-term crosssectional returns. I follow their approach and construct $\mathrm{V}$ via the Edwards-Bell-Ohlson (EBO) valuation technique based on analysts' consensus earnings forecasts. Then, $\mathrm{V} / \mathrm{P}$ ratio is $\mathrm{V}$ scaled by total market capitalization. Specifically, in this paper, I use the 24-month cumulative return as anomaly return by assuming that the portfolio for $\mathrm{V} / \mathrm{P}$ anomalies are held for 2 years after formation because $\mathrm{V} / \mathrm{P}$ ratio has good predictive power in a long term. All other anomalies in this paper use 1-month return after portfolio formation.

\section{METHODS}

I use the US equity market data from 1970 to 2018. Stock trading data come from CRSP. Financial statement data are obtained from COMPUSTAT. The analyst forecast data are acquired from I/B/E/S.

Only common stocks traded on NYSE, NASDAQ and AMEX (CRSP exchange code $=1,2,3$ and share code $=10,11$ ) are included in my analysis. Stocks with price per share less than $\$ 5$ or more than $\$ 1,000$ are excluded from my sample. I also adjust stock returns for delisting in order to avoid survivorship bias (Shumway, 1997).

2. Investor Sentiment

I measure investor sentiment using the monthly market-based sentiment series constructed by Baker and Wurgler (2006). The BW sentiment index spans over 49 years, from January 1970 to 
December 2018. Baker and Wurgler form their composite index by taking the first principal component of six measures of investor sentiment. The principal component analysis filters out idiosyncratic noise in the six measures and captures their common component. The six measures are the closed-end fund discount, the number and the first-day returns of IPOs, NYSE turnover, the equity share in total new issues, and the dividend premium.

\section{RESULTS AND DISCUSSIION}

Table 1 presents the summary statistics of the univariate analysis for each mispricing anomaly. Panel A uses raw returns and Panel B uses adjusted returns. For each mispricing anomaly, the returns of the long portfolios are economically higher and statistically more significant than those of the short portfolios, which confirms the validity for these six anomalies.

Table 1: Summary Statistics of Anomalies

Panel A: Raw Anomaly Returns

\begin{tabular}{cccc}
\hline & Long-short & long & Short \\
\hline Value premium & 0.008 & 0.016 & 0.008 \\
& $(3.8)$ & $(6.5)$ & $(2.3)$ \\
Earnings to price & 0.005 & 0.014 & 0.009 \\
& $(1.8)$ & $(6.3)$ & $(2.6)$ \\
Gross profitability & 0.004 & 0.011 & 0.007 \\
& $(2.1)$ & $(5.3)$ & $(0.88)$ \\
Operational & 0.007 & 0.010 & 0.003 \\
profitability & $(2.3)$ & $(5.1)$ & $(1.2)$ \\
Return on assets & 0.005 & 0.010 & 0.005 \\
& $(1.8)$ & $(4.9)$ & $(2.1)$ \\
V/P & 0.261 & 0.412 & 0.151 \\
& $(2.4)$ & $(5.6)$ & $(1.9)$ \\
\hline
\end{tabular}

Panel B: Adjusted by Fama-French three factors:

\begin{tabular}{cccc}
\hline & Long-short & Long & Short \\
\hline Value premium & 0.008 & 0.010 & 0.002 \\
& $(3.9)$ & $(7.0)$ & $(2.1)$ \\
Earnings to price & 0.007 & 0.005 & -0.002 \\
& $(3.1)$ & $(6.1)$ & $-0.8)$ \\
Gross profitability & 0.007 & 0.006 & -0.001 \\
& $(4.6)$ & $(7.7)$ & $(-0.6)$ \\
Operational & 0.009 & 0.006 & -0.004 \\
profitability & $(4.4)$ & $(10)$ & $-1.8)$ \\
Return on assets & 0.008 & 0.006 & -0.002 \\
& $(3.8)$ & $(10)$ & $(-1.2)$ \\
V/P & 0.227 & 0.342 & 0.116 \\
& $(2.2)$ & $(4.9)$ & $(1.4)$ \\
\hline
\end{tabular}

After adjusted by Fama and French three factors, investors get more long-short portfolio return than long or short portfolios for book-to-market, earnings-to-price, gross profitability, operating profitability and ROA anomalies. Operating profitability has the greatest portfolio return. In long portfolio, the actual return is largest for book-to-market anomaly. 
In bivariate analysis, I split the sample period into high sentiment period and low sentiment period according to the median investment sentiment of the whole sample period, and then compare the next-month returns of the anomalies between high sentiment periods and low sentiment periods.

Table 2 displays the bivariate analysis results for raw returns and Table 3 exhibits the effects for adjusted returns. In Table 2 and Table 3, there are five anomalies, earnings-to-price, GP, OP, ROA and $\mathrm{V} / \mathrm{P}$, have greater long-short portfolio returns for high investor sentiment than low sentiment (T statistics: $2.7,2.9,3.3,2.8,3.3$ ). Thus, for these anomalies in the long-short portfolio, they will be stronger when investor sentiment is high. While in long portfolios, apart from BP and earnings-toprice, stock returns are greater following high sentiment for other anomalies. In short portfolios, investors with high sentiment get negative returns for OP and ROA anomalies, and get lower returns for other four anomalies. Among these anomalies, $\mathrm{V} / \mathrm{P}$ anomaly follows the greatest short portfolio return, which indicates that there is a more serious stock overpricing for investors with high sentiment. Hence I find that for these anomalies in short portfolios, investors with low sentiment undervalue the stock and high-sentiment investors overpriced stocks. Additionally, the anomaly of $\mathrm{V} / \mathrm{P}$ ratio will have a stronger impact on the accuracy of investor valuations

Considering our hypothesis, which is that investors are more likely to misprice stocks when investor sentiment is high, leading to stronger mispricing anomalies in such higher investor sentiment periods.

Table 2: The Portfolio Returns Based on Investor Sentiment

\begin{tabular}{lllllllllll}
\hline & \multicolumn{3}{c}{ Long-short } & \multicolumn{3}{c}{ Long } & \multicolumn{3}{c}{ Short } \\
\hline & High & Low & $\begin{array}{l}\text { High- } \\
\text { Low }\end{array}$ & High & Low & $\begin{array}{l}\text { High- } \\
\text { Low }\end{array}$ & High & Low & $\begin{array}{l}\text { High- } \\
\text { Low }\end{array}$ \\
\hline BP & 0.007 & 0.009 & - & 0.013 & 0.019 & - & 0.006 & 0.010 & -0.004 \\
& $(2.6)$ & $(2.8)$ & 0.002 & $(4.54)$ & $(4.7)$ & 0.0057 & $(0.5)$ & $(2.7)$ & \\
EP & 0.011 & -0.002 & 0.012 & 0.013 & 0.014 & - & 0.003 & 0.016 & -0.013 \\
& $(2.7)$ & $(-0.4)$ & & $(4.9)$ & $(4.1)$ & 0.0009 & $(1.64)$ & $(2.0)$ & \\
GP & 0.007 & 0.001 & 0.006 & 0.012 & 0.009 & 0.0035 & 0.006 & 0.008 & -0.003 \\
& $(2.9)$ & $(0.2)$ & & $(4.6)$ & $(3.0)$ & & $(-0.8)$ & $(2.2)$ & \\
OP & 0.014 & -0.001 & 0.015 & 0.010 & 0.010 & - & -0.004 & 0.011 & -0.015 \\
& $(3.3)$ & $(-0.3)$ & & $(3.5)$ & $(3.7)$ & 0.0006 & $(-0.2)$ & $(2.0)$ & \\
ROA & 0.011 & -0.001 & 0.012 & 0.010 & 0.010 & - & -0.001 & 0.011 & -0.012 \\
& $(2.8)$ & $(-0.2)$ & & $(3.4)$ & $(3.6)$ & 0.0005 & $(1.1)$ & $(1.9)$ & \\
V/P & 0.491 & 0.019 & 0.472 & 0.577 & 0.213 & 0.363 & 0.086 & 0.194 & -0.108 \\
& $(3.3)$ & $(0.1)$ & $(2.4)$ & $(5.4)$ & $(2.2)$ & $(2.5)$ & $(0.7)$ & $(1.8)$ & $(-0.7)$ \\
\hline
\end{tabular}

Table3: The Portfolio Adjusted Returns Based on Investor Sentiment

\begin{tabular}{lllllllllll}
\hline & \multicolumn{3}{c}{ Long-short } & \multicolumn{3}{c}{ Long } & \multicolumn{3}{c}{ Short } \\
\hline & High & Low & $\begin{array}{l}\text { High- } \\
\text { Low }\end{array}$ & High & Low & $\begin{array}{l}\text { High- } \\
\text { Low }\end{array}$ & High & Low & $\begin{array}{l}\text { High- } \\
\text { Low }\end{array}$ \\
\hline BM & 0.007 & 0.008 & - & 0.008 & 0.012 & -0.004 & 0.001 & 0.003 & -0.002 \\
& $(2.7)$ & $(2.8)$ & 0.001 & $(4.8)$ & $(5.2)$ & & $(0.8)$ & $(2.3)$ & \\
EP & 0.011 & 0.003 & 0.008 & 0.005 & 0.005 & 0 & -0.005 & 0.003 & -0.008 \\
& $(3.5)$ & $(0.91)$ & & $(4.9)$ & $(3.9)$ & & $(-1.9)$ & $(0.9)$ & \\
GP & 0.010 & 0.004 & 0.006 & 0.009 & 0.003 & 0.006 & -0.001 & 0.001 & -0.002 \\
& $(4.9)$ & $(1.7)$ & & $(8.1)$ & $(2.7)$ & & $(-0.4)$ & $(-0.5)$ &
\end{tabular}




\begin{tabular}{lllllllllll}
\hline & \multicolumn{3}{c}{ Long-short } & \multicolumn{3}{c}{ Long } & \multicolumn{3}{c}{ Short } \\
\hline & High & Low & $\begin{array}{l}\text { High- } \\
\text { Low }\end{array}$ & High & Low & $\begin{array}{l}\text { High- } \\
\text { Low }\end{array}$ & High & Low & $\begin{array}{l}\text { High- } \\
\text { Low }\end{array}$ \\
\hline OP & 0.014 & 0.004 & 0.010 & 0.007 & 0.005 & 0.002 & -0.007 & 0.001 & -0.008 \\
& $(5.1)$ & $(1.3)$ & & $(9.2)$ & $(5.6)$ & & $(-2.8)$ & $(0.2)$ & \\
ROA & 0.012 & 0.004 & 0.007 & 0.007 & 0.004 & 0.003 & -0.005 & 0.000 & -0.005 \\
& $(4.4)$ & $(1.3)$ & & $(8.8)$ & $(5.1)$ & & $(-1.9)$ & $(0.0)$ & \\
V/P & 0.484 & 0.017 & 0.467 & 0.542 & 0.183 & 0.358 & 0.058 & 0.166 & 0.108 \\
& $(3.3)$ & $(0.1)$ & $(2.3)$ & $(5.0)$ & $(1.9)$ & $(2.5)$ & $(0.5)$ & $(1.6)$ & $(-0.7)$ \\
\hline
\end{tabular}

Table 4: Results for Regressions of Portfolio Returns over Investor Sentiment

\begin{tabular}{|c|c|c|c|c|c|c|}
\hline & \multicolumn{2}{|c|}{ Long-short } & \multicolumn{2}{|c|}{ Long } & \multicolumn{2}{|c|}{ Short } \\
\hline Anomaly & $\begin{array}{l}\text { Sentiment } \\
\text { coef }\end{array}$ & T statistic & $\begin{array}{l}\text { Sentiment } \\
\text { coef }\end{array}$ & $\begin{array}{l}\mathrm{T} \\
\text { statistic }\end{array}$ & $\begin{array}{l}\text { Sentiment } \\
\text { coef }\end{array}$ & T statistic \\
\hline $\begin{array}{l}\text { Book to } \\
\text { market }\end{array}$ & 0.006 & 1.55 & -0.005 & -1.07 & $-0.011^{* *}$ & -2.48 \\
\hline $\begin{array}{l}\text { Earrings to } \\
\text { Price }\end{array}$ & $0.017^{*}$ & 2.77 & -0.001 & -0.307 & $-0.018^{* *}$ & -2.26 \\
\hline $\begin{array}{l}\text { Gross } \\
\text { probability }\end{array}$ & $0.009^{* *}$ & 2.33 & -0.006 & -1.62 & $-0.015^{* * *}$ & -2.63 \\
\hline $\begin{array}{l}\text { Operational } \\
\text { profitability }\end{array}$ & $0.02^{* * *}$ & 3.21 & $-0.007^{*}$ & -1.83 & $-0.027^{* * *}$ & -3.35 \\
\hline $\begin{array}{l}\text { Return on } \\
\text { assets }\end{array}$ & $0.016^{* *}$ & 2.54 & $-0.008^{* *}$ & -1.98 & $-0.024^{* *}$ & -2.89 \\
\hline $\mathrm{V} / \mathrm{P}$ ratio & $0.210^{* *}$ & 2.03 & $0.105^{* * *}$ & 3.57 & $-0.059 *$ & -1.94 \\
\hline
\end{tabular}

Table 5: Results for Regressions of Portfolio Adjusted Returns over Investor Sentiment

\begin{tabular}{|c|c|c|c|c|c|c|}
\hline & \multicolumn{2}{|c|}{ Long-short } & \multicolumn{2}{|c|}{ Long } & \multicolumn{2}{|c|}{ Short } \\
\hline Anomaly & $\begin{array}{l}\text { Sentiment } \\
\text { coef }\end{array}$ & T statistic & $\begin{array}{l}\text { Sentiment } \\
\text { coef }\end{array}$ & $\begin{array}{l}\mathrm{T} \\
\text { statistic }\end{array}$ & $\begin{array}{l}\text { Sentiment } \\
\text { coef }\end{array}$ & T statistic \\
\hline $\begin{array}{l}\text { Book to } \\
\text { market }\end{array}$ & 0.006 & 1.49 & 0.004 & 1.39 & -0.002 & -1.13 \\
\hline $\begin{array}{l}\text { Earrings to } \\
\text { Price }\end{array}$ & $0.010^{* *}$ & 2.07 & $0.003^{*}$ & 1.68 & -0.007 & -1.50 \\
\hline $\begin{array}{l}\text { Gross } \\
\text { probability }\end{array}$ & $0.010^{* *}$ & 2.95 & $0.003^{*}$ & 1.85 & $-0.007^{* *}$ & -2.40 \\
\hline $\begin{array}{l}\text { Operational } \\
\text { profitability }\end{array}$ & $0.016^{* * *}$ & 3.67 & $0.003^{* *}$ & 2.57 & $-0.013^{* * *}$ & -3.25 \\
\hline $\begin{array}{l}\text { Return on } \\
\text { assets }\end{array}$ & $0.012^{* *}$ & 2.46 & $0.002^{* *}$ & 2.04 & $-0.009 * *$ & -2.07 \\
\hline $\mathrm{V} / \mathrm{P}$ ratio & $0.207^{* *}$ & 2.18 & $0.103^{* *}$ & 1.97 & $-0.012^{* * *}$ & -0.06 \\
\hline
\end{tabular}

*Significant at level of $0.1,{ }^{* *}$ Significant at level of 0.05 , and ${ }^{* * *}$ Significant at level of 0.01

In Tables 4 and 5, I regress anomalies over last-month investor sentiment, based on Regression analysis. For anomaly earnings-to-price, GP, OP, ROA and V/P in the long-short portfolio, the coefficient of investor sentiment last month is all positive. The $t$ statistics of these anomalies following high sentiment are significant. The P-value of earnings-to-price, GP, ROA and V/P are at a significance level of 0.05 , and OP is even more significant at the level of 0.01 . Thereby the regression coefficient is significantly different from hypothesized value, which means the long-short portfolio is substantial and rejects the null hypothesis. Thus, when the last month investor sentiment is high, 
the long-short portfolio return for the anomaly in next month will be higher, these anomalies are stronger. Afterwards, I robust the results by controlling Fama and French's 3 factors in Table 5. Then the new results for long-short portfolios roughly remain unchanged, which shows these mispricing anomalies have substantial effects on stock return when sentiment is high.

In long portfolios, after adjusting the effect by Fama and French three factors, I find for most anomalies, the portfolio returns are higher following high sentiment. While in short portfolios, the sentiment coefficient of all six anomalies is negative. GP, OP, ROA and V/P are at the significant level of 0.05 and 0.01 . Therefore, these anomalies in the short portfolio reject the null hypothesis. I can find that higher investor sentiment leads to less short portfolio return. Since in short portfolios, investors get more profits with lower short portfolio returns, this result suggests that investors are over-valuing stocks.

\section{CONCLUSION}

This paper investigated the effect of investor sentiment on mispricing anomalies. In the first part of this paper, I constructed three portfolios with long, short and long-short for each anomaly. In the second part, I conduct the bivariate analysis and regression analysis to test the change of portfolio returns with high investor sentiment and low investor sentiment and explore whether these anomalies will be stronger or weaker due to the shift in sentiment. To get a robust effect, I also adjusted the portfolio return by using Fama-French's three-factor model.

The major findings in this paper are as follows: 1) the mispricing anomalies are stronger when investor sentiment is higher; 2) when the investor sentiment is high, the short leg produces more negative returns for GP, OP, V/P and ROA and the long leg also produces more positive returns for earnings-to-price, GP, OP, V/P and ROA. These results show the level of investor sentiment affects investors' valuation accuracy on stock return and leads to stronger overpricing for overpriced stocks and stronger underpricing for underpriced stocks.

The contribution of this paper is I examine the stock return and investor valuation accuracy in relation to the investor sentiment. More importantly, investors with different level of sentiment will either under-value or overvalue the stock when the $\mathrm{V} / \mathrm{P}$ ratio is abnormal.

\section{REFERENCES}

Baker, M., Wurgler, J. (2006). Investor sentiment and the cross-section of stock returns. Journal of Finance 61, 1645-1680.

Ball, R. (1978). Anomalies in relationships between securities' yields and yield-surrogates. Journal of Financial Economics 6, 103-126.

Ball, R., J. Gerakos, J. T. Linnainmaa, and V. Nikolaev. (2015). “Deflating Profitability," Journal of Financial Economics 117, 225-248.

Chen, L., Novy-Marx, R., Zhang, L. (2010). An alternative three-factor model. Unpublished working paper. University of Rochester.

Fama, E. F., French, K. R. (1992). The Cross-Section of Expected Stock Returns. The Journal of Finance, 47(2), 427-465.

Frankel, R., Lee, C. M. C. (1998). Accounting valuation, market expection, and cross-sectional stock returns. Journal of Accounting and Economics, 25(1998), 283-319.

Novy-Marx, R. (2010). The Other Side of Value: Good Growth and the Gross Profitability Premium. 
NBER Working Paper, 15940.

Stambaugh, R. F., Yu, J. F., \& Yuan, Y. (2012). The Short of It: Investor Sentiment and Anomalies.Journal of Financial Economics. 104 (2), 288-302. 